Tomasz Sobieraj

\title{
Struktury w sieciach znaków. 0 próbie rekonstrukcji poetyki (kulturowej) poezji okresu pozytywizmu
}

Liryka polska powstająca po roku 1864, niegdyś lekceważona i uznawana za twórczość niedorównującą poezji wielkich poprzedników romantycznych, doczekała się ostatnimi czasy kilku interesujących egzegez, spośród których na plan pierwszy zdecydowanie się wybija monografia Tadeusza Budrewicza, krakowskiego uczonego, zatytułowana niepozornie i bezpretensjonalnie: Wierszobranie (druga połowa XIX wieku) ${ }^{1}$. Jest to próba wycinkowej, acz nader reprezentatywnej analizy językowo-stylistycznego modelu polskiej poezji postyczniowej - a więc zasadniczej części jej poetyki immanentnej a także interpretacji jej kulturowych znaczeń, które powstają wskutek sprzężenia zwrotnego między językiem poetyckim a rzeczywistością „zewnętrzną”. Dostęp do tej drugiej jest, jak wiadomo, zawsze zapośredniczony przez rozmaite sieci językowe (dyskursywne).

1 T. Budrewicz, Wierszobranie (druga połowa XIX wieku), Kraków 2016, ss. 239.
K r y $t$ y $k$ i : Tadeusz Budrewicz, Wierszobranie (druga połowa XIX wieku), Kraków 2016.

Budrewicz traktuje obiekt swoich analiz i interpretacji inaczej niż to dotąd bywało. Nie ustatycznia bowiem języka poezji jako artefaktu stabilnego i zamkniętego, widzi w nim manifestacje „antropologii słowa”, podkreślając na przykład fakt stopniowego przemieszczania się poezji z dziedziny sztuki wysokiej ku płaszczyźnie kultury popularnej, masowej, zdominowanej przez gust użytkowy. Uwzględnienie perspektywy socjologii literatury, a więc sfery odbioru poezji, pozwoliło autorowi sformułować istotne, odkrywcze uogólnienie na temat przesunięcia jej miejsca w ewoluującej kulturze społecznej oraz zmian, jakie ono wywoływało w jej strukturze:

Dotychczas takie teksty powstawały jako wyraz indywidualnego przeżycia twórcy, w epoce masowo wydawanych kurierów i dzienników stały się eleganckim towarem słownym, wytwarzanym i kopiowanym masowo na użytek konsumentów kultury popularnej. Poezja staje się elitarna, wierszowanie 
czy rymowanie - egalitarne [...]. Mowa wiązana, wiersz obsługuje literaturę piękną oraz piśmiennictwo użytkowe. To już chyba sfera pogranicza literaturoznawstwa. Rymowanki w obiegu publicznym można rozpatrywać w kategoriach kulturoznawstwa lub socjologii. Potrzeba zatem nowego języka opisu i innych kryteriów wartościowania².

I właśnie takie kategorie autor zaaplikował do swoich analiz, dzięki czemu jego wywód stał się wielopoziomowy: zarówno historycznoliteracki, jak i socjokulturowy. Poetyka poezji postyczniowej przejawia się tu jako struktura dynamiczna, kształtowana zarówno przez wybór autorski, jak i przez horyzont oczekiwań odbiorców, dialogująca z tradycją literacką oraz z kulturowym kontekstem epoki... Budrewicz nie „rozmywa” tekstowej substancji literatury; puntem wyjścia jest dla niego zawsze słowo poetyckie, traktowane jako wehikuł sensu. Tak się dzieje w odkrywczym studium Instrumentarium muzyczne w poezji postyczniowej, które fascynująco oświetla jedną z jej istotniejszych cech poetologiczno-estetycznych, a mianowicie „muzyczność” i „pieśniowość”, które nadawały charakterystycznego oblicza znacznej grupie wierszy. Budrewicz tworzy statystyczną listę tematów-słów o muzycznym znaczeniu, pojawiających się w liryce okresu pozytywizmu, ukazując tym sposobem wycinek ówczesnej polskiej kultury słowa, w którym przejawiał się określony „inwentarz form artystycznych”3. Wiersze osnute wokół motywów muzycznych pośrednio obrazowały dynamikę rozwoju społecznego. Autor książki dokonuje śmiałych uogólnień kulturowych, opartych na fundamencie językowo-stylistycznym. Świadomie upodrzędniając perspektywę podmiotową (czyli twórczość wybranych poetów) na rzecz ujęcia statystycznego, formułuje pionierską hipoteze o wewnętrznym skomplikowaniu poezji pozytywistycznej, o jej antynomiczności, powodowanej po części impulsami socjologiczno-literackimi:

Diapazon potoczności i elitaryzmu, dialektykę językowej organizacji tekstu fundowanej na realistycznej codzienności kultury emancypujących się mas

\footnotetext{
2 Tamże, s. 7.
}

3 Tamże, s. 18. drobnomieszczańskich, wyrobniczych i fabrycznych z jednej strony, a z drugiej - na upowszechnieniu - różnymi drogami - osiągnięć europejskiej sztuki najwyższej miary można obserwować w różnych tekstach ${ }^{4}$.

Muzyczny kod językowy spełniał istotne funkcje semantyczne. Poeci okresu pozytywizmu wykorzystywali go dość często, milcząco zakładając referencjalny charakter języka. W ich mniemaniu słowo mogło po prostu oddawać istotę ludzkiego doświadczenia w wymiarze zarówno jednostkowym (intymnie subiektywnym), jak i zbiorowym (społecznym). Jeśli powątpiewali w moc ekspresyjną i ewokacyjną słowa poetyckiego, to najczęściej czynili to w poczuciu własnej niedoskonałości kreacyjnej. Mogło się w takiej postawie przejawiać przekonanie o niedościgłej wyższości artyzmu wielkich romantyków. Z interpretacji Budrewicza wyłania się fascynująca konstrukcja myślowo-obrazowa, włączająca ów muzyczny kod językowy w sieć znaczeń społeczno-kulturalnych:

Pozytywistyczna lutnia to narzędzie niedoskonałe albo dopiero sposobi się do wydania dźwięku, albo ma uszkodzone struny, albo jest pęknięta...Wraz z wysoką frekwencją słowa „pieśń” oznacza, że poezja czasu pozytywizmu była w wysokim stopniu autotematyczna. Ówcześni lirycy nader często myśleli i pisali o procesie twórczym - samokrytycznie, nostalgicznie, smętnie, bez wiary we własne siły. Na podstawie analizy około 300 syntagm poetyckich, zawierających tematyczne odniesienia do muzyki instrumentalnej i wokalnej, można stwierdzić, że pozytywizm waloryzował harmonię, melodyjność, śpiewność, tak w wykonaniu orkiestralnym, jak i w odgłosach natury; motyw fortepianu często wprowadzał temat flirtu, a motyw rautu, balu, koncertu służył do satyrycznego przedstawiania rozwarstwień materialno-społecznych ${ }^{5}$.

Immanentne nakierowanie na sam tekst poetycki - jako odpowiednio zorganizowany układ językowy - prawdopodobnie nie pozwoliłoby odkryć kulturowej motywacji,

${ }^{4}$ Tamże, s. 20.

5 Tamże, s. 32-33 [wyróżnienie autora]. 
jaką dla ekspansji słownictwa muzycznego w poezji oraz „umuzycznienia” jej struktury była w XIX wieku polska kultura muzyczna, zdominowana przez pieśń, pełniącą ważną funkcję ideowo-patriotyczną. Jak bowiem zauważył Budrewicz:

W pieśni właśnie dopatrywano się narodowej polskiej cechy. Miała ona być „miłą przykrasą naszych zebrań towarzyskich", gwarancją moralnego ładu w narodzie, spoiwem łączącym kulturę szlacheckich dworków z kulturą mieszczańską. Ceniono melodie do tych pieśni łatwe, harmonijne, wpadające w ucho i „żłobiące się w pamięci”。

Ten swoisty dyktat pieśniowości miewał też niekorzystne konsekwencje dla poziomu artystycznego poezji, utrwalał bowiem jej rytmiczną konwencjonalność i tworzył zaporę przed inwencjami formalnymi. „Śpiewność” poezji polskiej okresu pozytywizmu stała się potem m.in. negatywnym punktem odniesienia dla eksperymentów awangardy modernistycznej lat dwudziestych następnego wieku.

Metodę statystyczną Budrewicz wykorzystał również w studium Rok 1885 w poezji naszej. Nikt wcześniej nie dokonał tak gruntownego przeglądu twórczości poetyckiej publikowanej wtedy na łamach najważniejszych periodyków warszawskich. Stworzona przez autora „ista rangowo-frekwencyjna" pozwoliła mu ugruntować formułowane sądy na empirycznym gruncie tekstowym. Wymowa liczb sugeruje konieczność zmiany wielu dotychczasowych opinii historycznoliterackich, które przedstawiały przynajmniej zniekształcony obraz sytuacji poezji w życiu literackim drugiej połowy XIX wieku. Budrewicz stwierdził:

Przegląd wskazuje, że potrzebne są dalsze badania, gdyż dostrzega się sygnały, które przeczą niektórym konstatacjom historycznoliterackim i historycznoprasowym o szczególnym zainteresowaniu//braku zainteresowania poezją niektórych czasopism. Przecenia się rolę „Świtu”, nie docenia tygodników pozytywistycznych, przychylnych liry- ce nieraz bardziej niż pisma „starej prasy”. Publikowanie w kilku nieco odmiennych programowo pismach dowodzi elastyczności ideowej samych poetów oraz redakcji; w każdym razie zdaje się dowodzić nieobecności silnych napięć, zbliżenia stanowisk, ujednolicenia świata przekonań i wartości, otwarcia się na dialog. Echa dawnych walk powracają potem tylko we wspomnieniach, grunt do krytycznego bilansu pozytywizmu był przygotowany - obrońcy nie manifestowali wojennej determinacji. Zgoła niepotrzebny był zmasowany atak na pozytywizm z wykorzystaniem liryki, pałającej żądzą odwetu za zniewagi „Przeglądu Tygodniowego" z pierwszych lat pisma. Niepotrzebny, bo dostrzegane przez wszystkich zagrożenia narodowego bytu i niekontrolowanego wybuchu społecznego ujednolicało postawy?

Jeśli świadomość „zagrożenia narodowego bytu” oraz narastających konfliktów socjalnych udzielała się wtedy w zasadzie wszystkim uczestnikom życia literackiego i mogła istotnie wpływać na pewne łagodzenie sporów, to jednak model języka poetyckiego okresu pozytywizmu ulegał już wewnętrznej dyferencjacji, powodowanej przez narastające społeczne i ekonomiczne zróżnicowanie zbiorowości, a także przez determinanty lokalne. Istotnym impulsem rozwojowym poezji okresu pozytywizmu okazał się czynnik, który dałoby się scharakteryzować jako element geopoetyki. Na przykład w Galicji - dzięki względnie liberalnym stosunkom społeczno-politycznym - nastąpił rozkwit poematu humorystycznego, który odegrał ważną rolę w dyskursie politycznym tego zaboru. Gatunek ten funkcjonował jako wehikuł sensów ideowo-politycznych ewokowanych przez skomplikowaną sieć znaków tworzących różne typy - powiązanych zresztą ze sobą - dyskursów: politycznego, ideologicznego, światopoglądowego, wreszcie etnokulturowego. Ostrzem satyry autorzy poematów atakowali dzierżące władzę w prowincji ugrupowanie stańczyków, które miało fatalne notowania w literaturze. Głośnym echem tematycznym odbiła się w tym gatunku także sprawa dyskutowanego na soborze dogmatu o niemylności papieża, wywołująca gwałtowne spory ideowe, 
religijne i nawet etniczne. Te ostatnie wiązały się z nastrojami antysemickimi, podsycanymi przez niektórych twórców o przekonaniach nacjonalistycznych.

Budrewicz wykazuje znakomitą orientację w kwestiach genologicznych. Problematyka gatunku odgrywała w badaniach historycznoliterackich i nadal odgrywa ogromną rolę; dość tu przypomnieć znakomite, klasyczne już prace polskich literaturoznawców: książkę Anny Martuszewskiej poświęconą poetyce powieści pozytywistycznej oraz monografię Michała Głowińskiego o powieści młodopolskiej.

Monografia Budrewicza częściowo nawiązuje do metodologii tych dwojga autorów; widać to choćby w próbach rekonstrukcji świadomości poetologicznej epoki, przejawiającej się w tekstach krytycznych i teoretycznych, formułujących poetykę normatywną poezji, a także w uwzględnieniu - wspomnianej wyżej - perspektywy gatunkowej. Ta ostatnia funkcjonuje ciągle w wielu propozycjach teoretycznych na gruncie literaturoznawstwa, i to nawet w tak nowatorskich ujęciach systemowych, jak na przykład to, które oferuje w swoich pracach Franco Moretti, tworzący mapę - opartego na matrycy biologiczno-ewolucyjnej - rozprzestrzeniania się powieści po różnych terytoriach świata i sytuujący ten gatunek zarówno w sieci powiązań historyczno- i teoretycznoliterackich, jak i w relacjach z dynamicznie rozwijającym się kontekstem społeczno-ekonomicznym ${ }^{8}$.

Monografia Budrewicza nie ma, rzecz jasna, tak szerokiego zaplecza teoretyczno-metodologicznego, zdawkowo uwzględnia perspektywę komparatystyczną, jednak poetyckie gatunki znajdują się w polu badawczej refleksji autora. Ich pojawienie się, rozwój, nieoczekiwaną ekspansję Budrewicz wiąże z przyczynami „zewnętrznymi”. Optyka kulturowa, sprzęgnięta z tradycyjnym podejściem historycznoliterackim, pozwoliła mu na sformułowanie odkrywczej hipotezy:

W zakresie form artystycznych zaskakuje niezwy-

8 Zob. T. Bilczewski, Wstęp, [w:] F. Moretti, Wykresy, mapy, drzewa. Abstrakcyjne modele na potrzeby historii literatury, przeł. T. Bilczewski, A. Kowalcze-Pawlik, Kraków 2016, s. XII i n. kła popularność sonetu. Każe to zrewidować pogląd o upadku formy sonetowej w pozytywizmie i jej twórczym odrodzeniu w liryce Młodej Polski. W połowie lat osiemdziesiątych można już widzieć „sonetomanię”. Szczególnie ciekawe są pod tym względem dokonania Szczęsnej (Bąkowskiej), która odważnie przekształcała format strof, rozbijając je na dystychy ulokowane w różnych miejscach struktury sonetu. Wtedy też dostrzega się epizację tej formy lirycznej i osłabienie dwudzielności opisowo-refleksyjnej. Takie zainteresowania forma stanowią łącznik z estetyką modernizmu. Częsta jest też modlitwa poetycka uprawiana i jako gatunek, i dla wyrażenia treści metafizycznych, które są wyraźne i niewątpliwie potwierdzają przełom w duchowości polskiej. Zaskakująco dużo wierszy mówi o śmierci - chodzi i o poetyckie epitafia, i o motyw tematyczny (trumna, żegnanie świata, jesienna „martwa” natura), przez który wyraża się światopoglądowy pesymizm [...]. W prasie codziennej częściej niż w tygodnikach pojawiały się utwory tematycznie związane ze zmianami pór roku. Wyraźna jest dominacja jesieni, ton elegijny i melancholijny, rozczarowanie światem, rezygnacja, szukanie stoickiej obojętności [...]. Spora część wierszy mogłaby być przedrukowana w antologii liryki Młodej Polski.

Poetyka poezji pozytywistycznej zyskuje tu zatem nowe oświetlenia, jej obraz dopełnia się o elementy wcześniej nieznane. Budrewicz świadomie rezygnuje z eksponowania poetyckich indywidualności epoki - choćby Konopnickiej albo Asnyka - kładąc akcent na płaszczyznę socjologii literatury, na dynamikę życia literackiego oraz jego związki z różnymi rodzajami znaków kulturowych, by tak rzec. Można stwierdzić, że autor stara się uchwycić struktury języka poetyckiego jako „płynne” konstrukcje artystyczne i jako wehikuły sensów. Dzięki takiej strategii heurystycznej powstał nowy obraz poetyki (kulturowej) poezji okresu pozytywizmu jako systemu wewnętrznych napięć ideowo-światopoglądowych i artystycznych, powstających na przecięciu sfer komunikacji społecznej: literatury oraz najrozmaitszych praktyk

9 T. Budrewicz, Wierszobranie..., s. 53-54. 
językowych (dyskursywnych). W uzasadnieniu obranej przez siebie strategii Budrewicz napisał:

Podstawowym założeniem było rozpatrzenie materiału poetyckiego en masse. Depersonalizacja pozwala na uchwycenie zjawisk psychospołecznych i trendów w estetyce, które nierzadko bywają przesłaniane przez eksponowanie indywidualnych cech podmiotowości jakiegoś twórcy. Spojrzenie na epokę z perspektywy codzienności, z pozycji przeciętnego czytelnika prasy, który wertował ogłoszenia, nekrologi, czytał artykuły wstępne, wiadomości miejscowe, cotygodniowe felietony, odcinki wypełnione literaturą piękną, a czasami również zamieszczone w gazetach wiersze, daje szanse dostrzeżenia spraw, problemów i nastrojów, których się nie zauważa ani w studiach historycznych, ani w pracach literaturoznawczych zorientowanych na eksplikację arcydzieł ${ }^{10}$.

Skrupulatne pochylenie się nad utworami poetów minorum gentium lub kompletnie nieznanych syntezom historycznoliterackim, powiązanie ich z problemami codzienności, odkrycie poetyckich refleksów ówczesnego życia kulturalnego w różnych jego przejawach i w lokalnej odmienności (ukazującej na przykład różnice geopoetologiczne) - wszystko to znajduje swoje zastosowanie w autorskiej praktyce czytania zarówno „bliskiego", skupionego na tkance tekstu, jak i operującego rozległym uogólnieniem. Monografia Budrewicza odkryła słabo dotąd rozpoznane lub nieznane w ogóle pola twórczości okolicznościowej i humorystycznej, w których - niczym w soczewce - skupiały się istotne cechy etnograficzno-kulturowe polskiej zbiorowości, ulegajacej demokratyzacyjnym zmianom społecznym w drugiej połowie XIX wieku. W zestawie wielu interesujących hipotez autora znalazła się i taka - zasygnalizowana nieco mimochodem - która podkreślała dominację świata maskulinistycznego w żartobliwej poezji epifanijnej.

Można zasadnie przypuścić, że przyjęta przez Budrewicza strategia egzegetyczna, nastawiona na odkry- wanie aspektów poetyki dzieł literackich zarówno poprzez tradycyjną - ugruntowaną choćby przez poetykę historyczną - analizę ich języka oraz konwencji gatunkowych, jak i przy zastosowaniu zmiennych, dynamicznych sieci znaków kulturowych, dałaby się zaaplikować do wielu obszarów empirii historycznoliterackiej. Oczywiście, można by oczekiwać aplikacji poszerzonej i pogłębionej, ukazującej na przykład statystyczne wykazy wykorzystywanych słów poetyckich z uwzględnieniem specyfiki i różnic lokalnych. Tym sposobem wytworzyłaby się szansa (re)konstrukcji wielopoziomowych poetyk (kulturowych) gatunków, stylów, prądów literackich, nieujmowanych już w „zamknięte” wyabstrahowane struktury, lecz dynamicznie wytwarzanych przez transfer idei oraz konwencji artystycznych między poziomami życia literackiego. 


\title{
SEOWA KLUCZOWE:
}

\author{
gatunki \\ socjologia literatury \\ języki poetyckie
}

kultura masowa

\begin{abstract}
ABSTRAKT:
Przedmiotem recenzji jest monografia Tadeusza Budrewicza pt. Wierszobranie (druga połowa XIX wieku) (Kraków 2016), stanowiąca przykład kulturowej interpretacji historycznoliterackiej, zorientowanej na (re) konstrukcję poetyk polskiej poezji drugiej połowy XIX wieku. Autor połączył kilka strategii egzegetycznych, udanie stosując metodę statystyczną oraz pewne kategorie geopoetyki. Poezja jawi się tu jako dynamiczny układ konwencji artystycznych, funkcjonujący w wielu kontekstach zewnętrznych i stymulowany przez różne obiegi literackie (w tym: obieg popularny). Z książki Budrewicza wyłania się złożony obraz etnokulturowy, w którym splatają się różnorodne wątki ideowe współtworzące polską świadomość kulturową drugiej połowy XIX wieku.
\end{abstract}

\section{NOTA O AUTORZE:}

Tomasz Sobieraj - profesor w Instytucie Filologii Polskiej UAM, historyk literatury drugiej okresu pozytywizmu. Ostatnie publikacje: Polska krytyka i myśl teatralna w drugiej połowie XIX wieku. Studia i szkice (2014), W sprawie przełomu pozytywistycznego. Spory wokót „Zarysu literatury polskiej z ostatnich lat szesnastu" Piotra Chmielowskiego (2015; współautor: Tadeusz Budrewicz), Stanisław Brzozowski. Przybliżenia (2016), edycja krytyczna Emancypantek Bolesława Prusa (vol. 1, 2015). 